\title{
Effect of Graphite Addition on Oxidation Behavior of Ni-Cr-Based Superalloy at $900{ }^{\circ} \mathrm{C}$
}

\section{Xue Maoquan}

\author{
Changzhou Institute of Light Industry Technology, Changzhou 213164, China
}

\begin{abstract}
Nickel-based alloys with different contents of graphite were prepared by powder metallurgy method. High temperature oxidation resistance of these alloys was studied by high temperature test at $900{ }^{\circ} \mathrm{C}$ for $100 \mathrm{~h}$ in static air. Morphology of oxides was studied by SEM and their composition was analyzed by XRD. The result shows that the kinetic curves of oxidation for nickel-based alloys with lower content of graphite obey the parabolic law. The oxide films consist of $\mathrm{Cr}_{2} \mathrm{O}_{3}$ and $\mathrm{NiCr}_{2} \mathrm{O}_{4}$ when the alloy contains no graphite. The oxide film consists of $\mathrm{Cr}_{2} \mathrm{O}_{3}$ when the alloy contains $3 \%$ graphite. If graphite content increases to $6 \%$, the oxidative decomposition of graphite leads to severe initial oxidation, and mass gain takes place significantly; the cavity after decomposition of graphite accelerates the process of oxidation reaction. The oxidation mechanism of the alloy has also been suggested by the phase composition analyses of oxide film.
\end{abstract}

Key words: Ni-based superalloy; graphite; oxidation kinetics; oxidation mechanism

Superalloy is a key material for turbine engine blades, advanced jet engines etc, and further improving of its anti-oxidation ability has been a very important subject in recent decades. Ni-Cr-based alloy ha not only excellent mechanical properties, but also the advantages of anti-oxidation and resistance to hot corrosion at ambient temperature and at elevated temperature, which makes them widely used in gas turbine, high temperatures engine, high temperatures boiler etc $^{[1-7]}$. Graphite is an effective lubricant additive for its self-lubricating properties deriving from its lamellar structure; therefore the usage scope of $\mathrm{Ni}$-Cr-based alloy at elevated temperature could be widened by the addition of graphite $e^{[8,9]}$. Oxidation is the most common corrosion mode, when parts and components serve in the high temperature environment. In recent years, the high temperature oxidation behavior of $\mathrm{Ni}-\mathrm{Cr}$-based alloy have been extensively studied ${ }^{[10-14]}$.

To access the performance of $\mathrm{Ni}-\mathrm{Cr}$ based alloy, the present work is to investigate the oxidation behavior of $\mathrm{Ni}-\mathrm{Cr}$ based alloys with strengthening phase tungsten and different contents of lubricant phase graphite. Strengthening phase $\mathrm{W}$ and lubricant phase graphite reinforced $\mathrm{Ni}-\mathrm{Cr}$ based alloys were developed by a powder metallurgy method, which are recommended to be used for high temperature applications.

\section{Experimental}

The chemical compositions of Ni-Cr based alloys are shown in Tab.1.

Alloyed Ni-20Cr powder, tungsten powder and graphite $[0 \%, 3 \%$ and $6 \%$ (mass fraction) $]$ were fully mixed to get the mixtures with different contents of graphite, and then the mixtures were cold pressed into green discs with $\Phi 45 \mathrm{~mm} \times 10$ $\mathrm{mm}$. Afterward the greens were hot pressed into the blanks in FVPHP-R-10 vacuum hot pressing furnace. The hot pressing conditions were as follows: pressure $16 \mathrm{MPa}$, temperature $1240{ }^{\circ} \mathrm{C}$, heating rate $20{ }^{\circ} \mathrm{C} / \mathrm{min}$, holding time $20 \mathrm{~min}$ and argon protection after degassing to $10^{-5} \mathrm{~Pa}$.

Table 1 Chemical compositions of $\mathrm{Ni}-20 \mathrm{Cr} /$ graphite composites (mass fraction, \%)

\begin{tabular}{ccc}
\hline $\mathrm{Ni}-20 \mathrm{Cr}$ & $\mathrm{W}$ & Graphite \\
\hline $76-85$ & 15 & $0-9$ \\
\hline
\end{tabular}

Received date: June 25, 2008

Foundation item: Project Supported by Qing Lan Project of Jiangsu Province

Biography: Xue Maoquan, Master, Lecturer, Changzhou Institute of Light Industry Technology, Changzhou 213164, P.R. China, Tel: 0086-519-86335162, E-mail: xuemaoq@yahoo.com.cn

Copyright (C) 2009, Northwest Institute for Nonferrous Metal Research. Published by Elsevier BV. All rights reserved. 
The alloy blanks were fabricated into the samples with 10 $\mathrm{mm} \times 4 \mathrm{~mm} \times 4 \mathrm{~mm}$, which were ground with emery papers washed in water, alcohol and finally dried. The oxidation dynamic experiments of the alloys were performed in a chamber furnace at $900{ }^{\circ} \mathrm{C}$ for $100 \mathrm{~h}$ in air. After being oxidized for certain time $(1,3,5,10,25,50,75$ and $100 \mathrm{~h})$ the samples were taken out and weighed by DT2100 analytical balance with an accuracy of $0.1 \mathrm{mg}$. The phase constitutions were analyzed by XRD, and the morphologies of the sample cross sections were observed by SEM.

\section{Results and Discussion}

\subsection{Morphology and structure of alloys}

Fig. 1 shows the morphologies and XRD pattern of the alloys after hot pressing. There are a few gray blocks and black dot impurity phases dispersed in the matrix of the alloy with no graphite addition, as shown in Fig.1a. The gray blocks and black dots increase with the increase of graphite content. XRD result indicates that besides some Ni-based solution and graphite, there are a few tungsten carbides, which were formed by tungsten and graphite reaction.
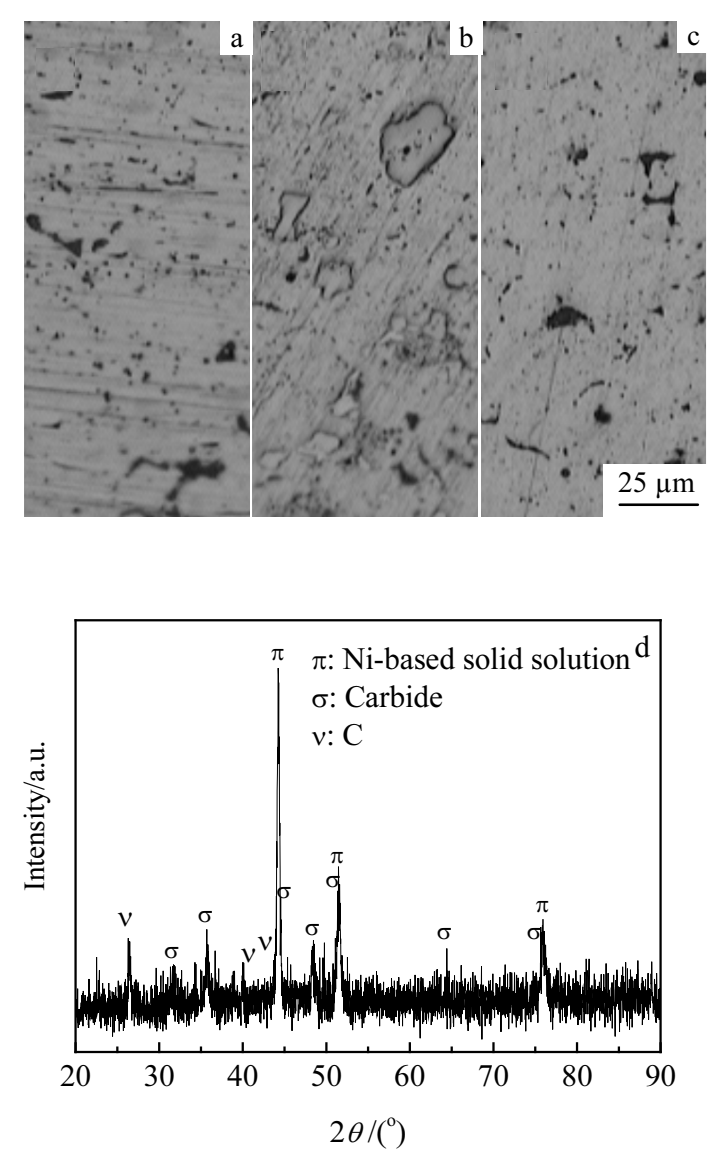

Fig.1 Optical photographs of the alloys with different contents of graphite (mass fraction): (a) $0 \%$; (b) $3 \%$; (c) $6 \%$; and (d) XRD pattern of $\mathrm{P} / \mathrm{M}$ products of $\mathrm{Ni}-\mathrm{Cr}-\mathrm{W}-\mathrm{C}$ alloy

\subsection{Oxidation dynamic curve}

The oxidation dynamic curves of the alloys with different contents of graphite $(\mathrm{A}=0 \%, \mathrm{~B}=3 \%, \mathrm{C}=6 \%)$ (mass fraction) at $900{ }^{\circ} \mathrm{C}$ for $100 \mathrm{~h}$ are presented in Fig.2. In initial period of 10 $\mathrm{h}$, oxidation speeds up. This is the formation period of oxide film. Then, the oxidation speeds down, and enters the oxide film growth period, which lasts for $20 \mathrm{~h}$. During the oxidation process, a surface reaction changes into diffusion gradually. At the same temperature, the mass gain of the alloy with addition of $3 \%$ (mass fraction) graphite is higher than that of $\mathrm{Ni}-\mathrm{Cr}-\mathrm{W}$ alloy; however, the mass gain of the alloy with addition of $6 \%$ (mass fraction) graphite is the lowest. According to the dynamics curve, the equation can be written as $\Delta m=a t^{b}$, where $\Delta m$ is the mass gain and $t$ is the oxidization time. From the equation, the formula of $\mathrm{Ni}-\mathrm{Cr}-\mathrm{W}$ alloy at $900{ }^{\circ} \mathrm{C}$ is $\Delta m=0.27 t^{0.30}$. It can be concluded that the oxide dynamic curve approximately follows cube rule, which shows that the oxides formed at high temperature have a restraining effect on oxidation process. The formula is changed into $v=0.08 t^{-0.70}$, through a derivative transformation, where $v$ is the oxidation velocity. The formula of sample $\mathrm{B}$ and $\mathrm{C}$ at $900{ }^{\circ} \mathrm{C}$ is $\Delta m=0.36 t^{0.30}$ and $\Delta m=0.16 t^{0.26}$ respectively. The formula is changed into $v=0.11 t^{-0.70}$ and $v=0.04 t^{-0.74}$ respectively, through a derivative transformation. It can be concluded that oxidation speeds down with prolonging of the time.

\subsection{Constitution of oxidation film}

Fig. 3 shows the SEM images of the samples with different contents of graphite $(\mathrm{A}=0 \%, \mathrm{~B}=3 \%, \mathrm{C}=6 \%$ )(mass fraction) at $900{ }^{\circ} \mathrm{C}$ after $100 \mathrm{~h}$ oxidation. Fig. 4 shows X-ray diffraction results for the surface of the samples after oxidation. It can be seen that there are dense oxidation films on the surface without graphite. The oxides on the surface consist of $\mathrm{Cr}_{2} \mathrm{O}_{3}$ and $\mathrm{NiCr}_{2} \mathrm{O}_{4}$ spinelle. With $3 \%$ (mass fraction) content of graphite, the oxide grains on the surface become larger and more protruded, the main component of the oxidation film is $\mathrm{Cr}_{2} \mathrm{O}_{3}$, and oxidation mass gain is higher than that of sample $\mathrm{A}$,

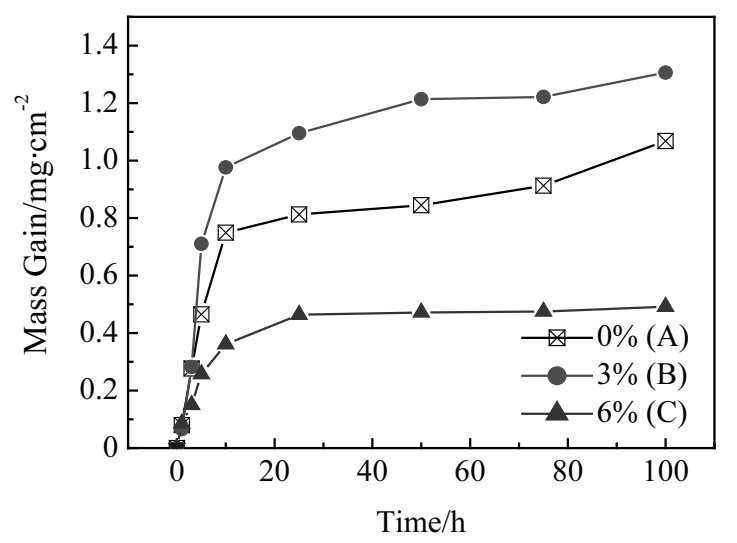

Fig.2 Oxidation kinetics curves of Ni-based alloys in air at $900{ }^{\circ} \mathrm{C}$ for $100 \mathrm{~h}$ 


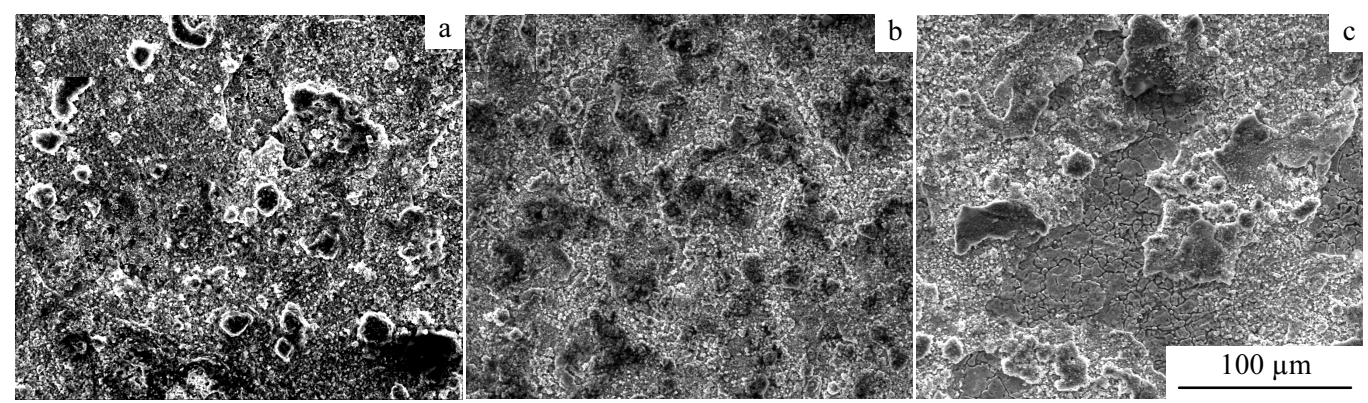

Fig.3 SEM images of samples oxidized for $100 \mathrm{~h}$ at $900{ }^{\circ} \mathrm{C}$ : (a) Ni-Cr-W-0\%C; (b) Ni-Cr-W-3\%C; and (c)Ni-Cr-W-6\%C
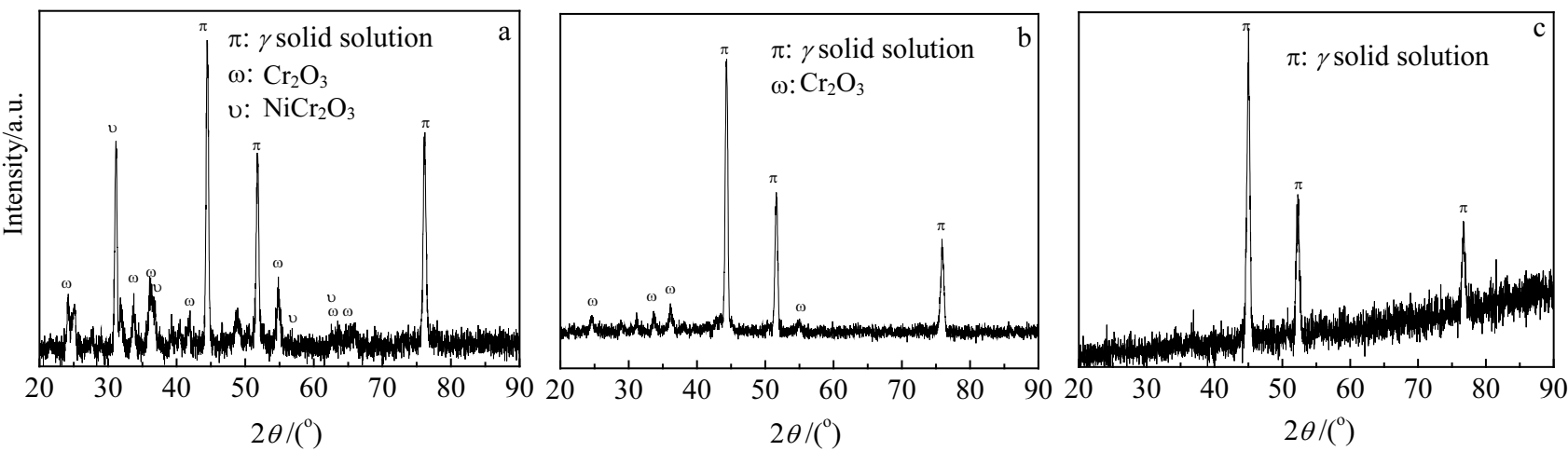

Fig.4 XRD patterns of samples after oxidation for $100 \mathrm{~h}$ at $900{ }^{\circ} \mathrm{C}$ : (a) $\mathrm{Ni}-\mathrm{Cr}$; (b) Ni-Cr-W-3\%C; and (c) Ni-Cr-W-6\%C

as shown in Fig.2. When the alloy with $6 \%$ mass fraction) content of graphite, the oxides flake away, resulting in the matrix oxidized further; there are only a few oxides on the surface instead of continuous oxide films, which means that the alloy has no ability of oxidation resistance. In each sample there is $\gamma$ phase (nickel base solid solution); this is because the oxides thickness was limited in the oxidation process, X-ray penetration depth is large, thus penetrate oxide layer, and shows the phase constitution of the substrate material.

The addition of $\mathrm{W}$ promotes strengthening of the solid solution, raising recrystallization temperature of the matrix and reducing the diffusion rate of atoms in the matrix. Some research indicated that a selective oxidation for nickel-based alloy will occur when the content of active lively element chromium in the nickel-based alloy exceeds a critical concentration, resulting in the formation of single $\mathrm{Cr}_{2} \mathrm{O}_{3}$ oxide layer ${ }^{[1]}$. The oxidation of graphite in the alloy will occur at high temperature, and part of it becomes gas which escapes, resulting in the formation of the cavity in the oxide film. Metal transporting outward will take place through oxide film and cavity in next oxidation process; along with the oxidation, the curve of oxide film will exacerbate ${ }^{[15]}$, and the oxide shedding happens when the curve of oxide reaches a certain degree. Upon the lower content of graphite, the oxidations of graphite and metal matrix take place simultaneously in oxidation process; however, the oxidation mass gain significantly exceeds the gas escape.
The effect of graphite oxidation on the oxidation resistance of alloys increases with increasing of graphite content.

\section{Conclusions}

1) The graphite content of Ni-Cr-based alloy has the remarkable influence on the oxidation resistance and oxidation mechanism at $900{ }^{\circ} \mathrm{C}$.

2) The isothermal oxidation kinetics of the alloy containing various contents of graphite obeys the parabolic law at 900 ${ }^{\circ} \mathrm{C}$.

3) Without graphite, the dense oxidation film of Ni-Crbased alloy consists of spinel structure $\mathrm{NiCr}_{2} \mathrm{O}_{4}$ and $\mathrm{Cr}_{2} \mathrm{O}_{3}$, and the oxidation rate of the alloy is reduced. With the addition of graphite, a loose $\mathrm{Cr}_{2} \mathrm{O}_{3}$ film on composite surface will be formed, and the oxidation rate increases.

\section{References}

1 Zhu Rizhang(朱日彰), He Yedong(何业东), Qi Huibin(齐慧滨). High Temperature Corrosion and Material Resist to High Temperature Corrosion(高温腐蚀及耐高温腐蚀材料)[M]. Shanghai: Shanghai Science and Technology Press, 1995

2 Xiang J H, Gesmundo F, Niu Y. Corrosion Science[J], 2004, 46: 2025

3 Ren Xin, Wang Fuhui, Wang Xin. Surface and Coatings Technology[J], 2005, 198: 425

4 De Julian Fernandez C, Mattei G, Sada C et al. Materials Sci 
ence and Engineering $C[\mathrm{~J}], 2006,26: 987$

5 Lopez-Beltran A M, Mendoza-Galvan A. Thin Solid Films [J], 2006, 503: 40

6 Cao Z Q, Shen Y, Liu W H et al. Materials Science and Engineering $A[\mathrm{~J}], 2006,425: 138$

7 Alexander Winkler, Holger Borchert, Katharina Al-Shamery. Surface Science[J], 2006, 600: 3036

8 Li Jianliang, Xiong Dangsheng, Dai Junfen. Trans Nonferrous Met Soc China[J], 2005, 15(S3):171

9 Xiong Dangsheng, Wan Yi, Lin Jianming et al. Trans Nonferrous Met Soc China[J], 2005, 15(S3): 162

10 Ramesh Bapu G N K, Sobha Jayakrishnan . Materials Chemistry and Physics[J], 2006, 96: 321
11 Morales-Rodrguez A, Bravo-Leon A, Richter G et al. Scripta Materialia[J], 2006, 54: 2087

12 Huang L, Sun X F, Guan H R et al. Surface and Coatings Technology[J], 2006, 200: 6863

13 Zheng Danliang(郑旦亮), Zhu Dingyi(朱定一), Chen Liyu(陈立 宇). Journal of Fujian University of Technology(福建工程学院 学报)[J], 2005, 3(6): 590

14 Jiang Jianmin(蒋建敏), Dong Na (董_娜), He Dingyong(贺定勇) et al. Chinese Journal of Rare Metals(稀有金属)[J], 2006, 30(1): 34

15 Li Meishuan(李美栓). Metal Corrosion at High Temperatures (金属的高温腐蚀) [M]. Beijing: Metallurgical Industry Press, 2001

\title{
石墨含量对镍基高温合金在 $900{ }^{\circ} \mathrm{C}$ 氧化行为的影响
}

薛茂权

(常州轻工职业技术学院, 江苏 常州 213164)

\begin{abstract}
摘 要: 采用粉末冶金方法制备不同石墨含量 $\left(0 \% 、 3 \% 、 6 \%\right.$ )的镍基高温合金, 研究合金材料在 $900{ }^{\circ} \mathrm{C}$ 和 $100 \mathrm{~h}$ 下的恒温氧化行为, 用 扫描电镜和 $X$ 射线衍射对其氧化表面形貌和成分进行观察和分析。结果表明: 石墨含量较低( $0 \%, 3 \%)$ 时, 镍基合金氧化动力学符合抛 物线规律, 表面氧化膜无剥落; 石墨含量为 $0 \%$ 的合金氧化膜由 $\mathrm{Cr}_{2} \mathrm{O}_{3}$ 和 $\mathrm{NiCr}_{2} \mathrm{O}_{4}$ 组成, 石墨含量为 $3 \%$ 的合金氧化膜由 $\mathrm{Cr}_{2} \mathrm{O}_{3}$ 组成, 当 石墨含量增加到 $6 \%$ 时，大量石墨的氧化分解导致合金初始氧化严重，石墨分解后的孔洞加速氧化反应过程。根据氧化膜的组成分析了 合金的氧化机制。
\end{abstract}

关键词: 镍基高温合金; 石墨; 氧化动力学; 氧化机制

作者简介: 薛茂权, 男, 1978 年生, 硕士, 讲师, 常州轻工职业技术学院, 江苏 常州 213164, 电话: 0519-86335162, E-mail:xuemaoq@yahoo.com.cn 